\title{
Intermediate filament cytoskeleton of the liver in health and disease
}

\author{
P. Strnad · C. Stumptner · K. Zatloukal · H. Denk
}

Accepted: 14 April 2008 / Published online: 29 April 2008

(C) Springer-Verlag 2008

\begin{abstract}
Intermediate filaments (IFs) represent the largest cytoskeletal gene family comprising $\sim 70$ genes expressed in tissue specific manner. In addition to scaffolding function, they form complex signaling platforms and interact with various kinases, adaptor, and apoptotic proteins. IFs are established cytoprotectants and IF variants are associated with $>30$ human diseases. Furthermore, IF-containing inclusion bodies are characteristic features of several neurodegenerative, muscular, and other disorders. Acidic (type I) and basic keratins (type II) build obligatory type I and type II heteropolymers and are expressed in epithelial cells. Adult hepatocytes contain K8 and K18 as their only cytoplasmic IF pair, whereas cholangiocytes express K7 and K19 in addition. K8/K18-deficient animals exhibit a marked susceptibility to various toxic agents and Fasinduced apoptosis. In humans, K8/K18 variants predispose to development of end-stage liver disease and acute liver failure (ALF). K8/K18 variants also associate with development of liver fibrosis in patients with chronic hepatitis C. Mallory-Denk bodies (MDBs) are protein aggregates consisting of ubiquitinated $\mathrm{K} 8 / \mathrm{K} 18$, chaperones and sequestosome1/p62 (p62) as their major constituents. MDBs are found in various liver diseases including alcoholic and nonalcoholic steatohepatitis and can be formed in mice by feeding hepatotoxic substances griseofulvin and 3,5-diethoxycarbonyl-1,4-dihydrocollidine (DDC). MDBs also arise
\end{abstract}

C. Stumptner $\cdot$ K. Zatloukal $\cdot$ H. Denk $(\bowtie)$

Institute of Pathology, Medical University of Graz,

Auenbruggerplatz 25, $8036 \mathrm{Graz}$, Austria

e-mail: helmut.denk@meduni-graz.at

P. Strnad

Department of Internal Medicine I, University of Ulm,

Robert-Koch-Straße 8, 89081 Ulm, Germany

e-mail: Strnad@stanford.edu in cell culture after transfection with $\mathrm{K} 8 / \mathrm{K} 18$, ubiquitin, and p62. Major factors that determine MDB formation in vivo are the type of stress (with oxidative stress as a major player), the extent of stress-induced protein misfolding and resulting chaperone, proteasome and autophagy overload, keratin 8 excess, transglutaminase activation with transamidation of keratin 8 and p62 upregulation.

Keywords Keratin · Mallory-Denk body · Aggregate · Inclusion · Variant · p62 - Ubiquitin · Oxidative stress . Steatohepatitis

\section{Intermediate filaments in health and disease}

Together with the actin microfilaments and the microtubules, intermediate filaments (IFs) are the components of the cytoskeleton of eukaryotic cells, which is involved in the maintenance of cell shape, locomotion, intracellular organization, and transport (Bershadsky and Vasiliev 1988; $\mathrm{Ku}$ et al. 1999). IF proteins comprise a large family, which includes $\sim 70$ different genes (Omary et al. 2004; Kim and Coulombe 2007; Herrmann et al. 2007; Goldman et al. 2008). They are further divided into six subtypes (Table 1), which are, at least in part, expressed in a cell type (and differentiation)-dependent manner (Omary et al. 2004; Kim and Coulombe 2007; Goldman et al. 2008). Accordingly, IFs serve as cell type markers and antibodies to IF proteins are widely used today in diagnostic pathology (Wick 2000; Barak et al. 2004). Individual IF proteins consist of a conserved central coiled-coil $\alpha$-helical rod domain (interrupted by linkers) which is flanked by N-terminal (head) and C-terminal (tail) domains (Omary et al. 2006; Godsel et al. 2008; Kim and Coulombe 2007; Herrmann et al. 2007; Goldman et al. 2008). The N- and C-terminal domains 
Table 1 Intermediate filament proteins

\begin{tabular}{|c|c|c|c|}
\hline Type & Name/Localization & Disease location & Remarks \\
\hline $\mathrm{I}(n=28)$ & $\begin{array}{l}\text { K9-28 (epithelia) } \\
\text { K31-40 (hair/nail) }\end{array}$ & $\begin{array}{l}\text { K10,14,16,17-skin } \\
\text { K12-cornea } \\
\text { K13-stratified mucosa } \\
\text { K16,17-nail } \\
\text { K18 -liver }\end{array}$ & $\begin{array}{l}\text { Acidic keratins } \\
(\mathrm{pI}<5.7) \\
\text { Type I/II obligate } 1: 1 \text { polymers }\end{array}$ \\
\hline II $(n=26)$ & $\begin{array}{l}\text { K1-8, K71-80 (epithelia) } \\
\text { K81-86 (hair/nail) }\end{array}$ & $\begin{array}{l}\text { K1,2e,5,9-skin } \\
\text { K3-cornea } \\
\text { K4-stratified mucosa } \\
\text { K6a,6b-nail } \\
\text { K8 -liver } \\
\text { K75 a ,81,83,85,86-hair }\end{array}$ & $\begin{array}{l}\text { Basic keratins } \\
(\mathrm{pI} \geq 6.0) \\
\text { Type } \mathrm{I} / \mathrm{II} \text { obligate } 1: 1 \\
\text { polymers }\end{array}$ \\
\hline III & $\begin{array}{l}\text { Desmin (muscle) } \\
\text { Vimentin (mesenchymal) } \\
\text { Peripherin (neurons) } \\
\text { GFAP (astrocytes/glia) }\end{array}$ & $\begin{array}{l}\text { Brain }^{\mathrm{a}}, \text { spinal cord } \\
\text { Brain }\end{array}$ & $\begin{array}{l}\text { Desmin, vimentin and GFAP are } \\
\text { found in stellate cells }\end{array}$ \\
\hline IV & $\begin{array}{l}\text { NF-L (neurons) } \\
\text { NF-M (neurons) } \\
\text { NF-H (neurons) } \\
\alpha \text {-internexin (CNS neurons) } \\
\text { Synemins (muscle) } \\
\text { Syncoilin (muscle) } \\
\text { Nestin }\end{array}$ & $\begin{array}{l}\text { Brain }^{\mathrm{a}} \text {, spinal cord } \\
\text { Brain }^{\mathrm{a}}, \text { spinal cord }^{\mathrm{a}} \\
\text { Brain, spinal cord }^{\mathrm{a}}\end{array}$ & $\begin{array}{l}\text { Synemin } \beta \text { is also called desmuslin. } \\
\text { Nestin-stem cell marker }\end{array}$ \\
\hline V & $\begin{array}{l}\text { Lamin A/C (ubiquitous) } \\
\text { Lamin B1/2 (ubiquitous) }\end{array}$ & $\begin{array}{l}\text { Heart, muscle, fat, premature } \\
\text { aging, complex defects }\end{array}$ & The only nuclear IFs, longer rod domain \\
\hline Orphan & $\begin{array}{l}\text { Phakinin (lens) } \\
\text { Filensin (lens) }\end{array}$ & $\begin{array}{l}\text { Lens } \\
\text { Lens }\end{array}$ & Beaded filaments in lens epithelia \\
\hline
\end{tabular}

a Not a causative association, variants represent a risk factor. For an overview about the new keratin nomenclature, see Schweizer et al. (2006)

contribute to the structural heterogeneity and are major sites of posttranslational modifications with phosphorylation being the best characterized one (Omary et al. 1998; 2006). This makes them important regulatory domains, since dynamic changes in phosphorylation status are responsible for alterations in IF dynamics, solubility, and organization (Omary et al. 2006).

In addition to the posttranslational modification, IF function is modified and complemented through interaction with a variety of IF-associated proteins (IFAP; Table 2; Green et al. 2005; Omary et al. 2006; Kim and Coulombe 2007). These proteins can be subdivided into several subgroups, which reflect multiple IF functions (Green et al. 2005). For example, IFs interact with a variety of anchoring proteins thereby forming transcellular networks which contribute to proper tissue architecture. IFAPs also include several cytolinker proteins, which provide the structural framework for coordinated cytoskeletal function (Table 2). By doing that, they are important mechanical stabilizers and accordingly, IF disruption results in increased mechanical fragility (Omary et al. 2004; Ku et al. 2007; Herrmann et al. 2007). The scaffolding function of IFs is best seen in IF-deficient animals, who exhibit disrupted cellular architecture, protein mistargeting as well as alterations in organelle localization and function (Toivola et al. 2005). In the case of lamin deficiencies, the impairment of nuclear composition has profound impact on many aspects of normal nuclear functions such as epigenetic changes, chromatin organization or DNA transcription, and repair (Dechat et al. 2008).

IFs are not just simple cellular scaffolds, they rather build complex signaling platforms (Pallari and Eriksson 2006; Kim and Coulombe 2007). IFs interact with a variety of enzymatic and adaptor proteins, thereby affecting a multitude of cellular functions. For example, keratins associate with 14-3-3 proteins in a phosphorylation-dependent manner and this interaction regulates cell growth and cell cycle progression (Ku et al. 2007; Kim and Coulombe 2007). IF 
Table 2 Examples of IF-associated proteins

\begin{tabular}{lll}
\hline Type of interaction & Examples & Function \\
\hline Anchoring & Desmoplakin, BPAG1, $\alpha$-dystobrevin & Tissue architecture \\
Cytolinker & Plectin, Filaggrin, & Cellular architecture \\
Chaperones & Hsp27, $\alpha$-B-crystallin, Hsp70 & Protein folding \\
Kinases & PKC, Cdk5 & IF regulation, phosphate sink, \\
& & cell cycle \\
Adaptor proteins & 14-3-3 protein, AP-3 & Multiple effects \\
Membrane proteins & Polycystin-1 & Unknown \\
Apoptotic proteins & TRADD, TNFR2, C-Flip, Caspase3/9 & Apoptosis regulation \\
Motor proteins & Dynein, Kinesin & Movement of IF components \\
\hline
\end{tabular}

phosphorylation through associated kinases does not only regulate IF properties, but IFs also serve as phosphate "sponge" thereby preventing activation of other, potentially pro-apoptotic, substrates (Omary et al. 2006; Ku et al. 2007). In addition to that, IFs also directly participate in apoptosis regulation through binding of several apoptosisrelated molecules (Marceau et al. 2007).

In contrast to the actin and tubulin system, IFs emerged later in the evolution and are important supportive elements of the cell rather than their essential components. Therefore, IF variants are observed in various human diseases, which reflect their tissue specific distribution, whereas only few actin and tubulin variants have been described so far, likely due to their embryolethality (Ku et al. 1999; Omary et al. 2004). Currently, more than 30 diseases are caused by/associated with IF mutations (Omary et al. 2004). Among them, keratin-related- and lamin-related disorders are the best studied ones. For example, mutations in keratins 5/14 cause a blistering skin disease termed Epidermolysis bullosa simplex, whereas mutations in lamins $\mathrm{A}$ and $\mathrm{C}$ result, among others, in different diseases including premature aging, cardiomyopathy, and lipodystrophy (Omary et al. 2004; Dechat et al. 2008).

The disease relevance of IFs is also highlighted by a variety of IF-containing inclusion bodies, which represent the pathological hallmarks of several neurodegenerative, muscular, and other disorders (Goebel 1998; Ross and Poirier 2004; Omary et al. 2004; Cairns et al. 2004). These aggregates share a variety of features such as presence of misfolded, ubiquitinated structural proteins together with variable amounts of chaperones and p62 (Kuusisto et al. 2001; Zatloukal et al. 2002; Ross and Poirier 2004). Among the IFrelated inclusions, Mallory-Denk bodies (MDBs) are the most common and also the best studied ones due to the availability of animal MDB models (Denk et al. 1975; Yokoo et al. 1982; Jensen and Gluud 1994; Denk et al. 2000; Zatloukal et al. 2007). Therefore, one focus of our review will be to describe MDB as a prototype of IF-related inclusion body, which should offer useful insights into the formation of IFrelated aggregates in multiple human diseases.

\section{Keratins as epithelially expressed IFs}

Keratins represent the largest subfamily of IFs consisting of $>50$ unique gene product members (Schweizer et al. 2006; Kim and Coulombe 2007; Godsel et al. 2008) which include 37 epithelial and 17 hair keratin members in humans (Table 1; Schweizer et al. 2006). Based on their pI, epithelial keratins can be subdivided in types I (acidic) and II (basic) corresponding to keratins 9-20 (K9-K28) and keratins 1-8 plus keratins 71-80 (K1-K8; K71-K80), respectively (Table 1; Coulombe and Omary 2002; Schweizer et al. 2006). Keratins are found as obligatory type I and type II heteropolymers (i.e., consisting of at least one type I and one type II keratin) and a homozygous disruption of a keratin results in degradation of its keratin partner at the protein level ( $\mathrm{Ku}$ and Omary 2000; Omary et al. 2004). Similarly to IFs, keratins are expressed in a tissuespecific manner, with different pairs being the major cellular IFs in different cell populations (Moll et al. 1982; Ku et al. 1999; Coulombe and Omary 2002). For example, "simple" (i.e., single layered) epithelia, as found in digestive organs, express $\mathrm{K} 8$ together with variable levels of $\mathrm{K} 7, \mathrm{~K} 18$, K19, and K20 depending on the tissue (Moll et al. 1982; Ku et al. 1999; Coulombe and Omary 2002; $\mathrm{Ku}$ et al. 2007). In contrast, stratified epithelia, like epidermis, express $\mathrm{K} 5 / \mathrm{K} 14$ in the basal and $\mathrm{K} 1 / \mathrm{K} 10$ in the suprabasal keratinocytes, respectively (Moll et al. 1982; Lane and McLean 2004; Coulombe and Omary 2002). Despite their similar molecular composition, "simple" and "stratified" keratins are not interchangeable, as shown in K14null mice, whose phenotype was only partially restored by addition of K18 (Hutton et al. 1998). Furthermore, keratins have their preferential binding partners in vivo and the lack of such partner leads to their rapid degradation (Magin 1998). This contrasts with the in vitro situation, where IF assembly is more promiscuous (Hatzfeld and Franke 1985).

K8/K18/K19 are promising serological markers based on their high abundance (approximately $0.3 \%$ of total liver protein) and intracellular localization under basal condi- 
tions with release into blood upon liver injury (Omary et al. 2002; Ku et al. 2007). However, one important caveat is the fact, that K8/K18/K19 are expressed in most simple epithelial cells and are therefore not liver-specific (Moll et al. 1982; Ku et al. 1999).

The K8/K18/K19 epitopes used in serologic diagnosis can be divided into two classes, that is, non-specific and apoptosis-generated epitopes. The former class constitutes established tumor markers such as tissue polypeptide antigen (TPA, represents total K8/K18/K19), tissue polypeptide specific antigen (TPS, derived from K18), and CYtokeratin FRAgment 21-1 (CYFRA 21-1, derived from K19). Their original clinical use was to monitor treatment response and to detect recurring tumors (Barak et al. 2004). However, later studies showed that these epitope serum levels are also elevated in non-malignant diseases and might be a general marker of tissue injury (Gonzalez-Quintela et al. 2006a, b; Tarantino et al. 2007).

The apoptosis-specific keratin antibodies are based on the finding, that type I keratins are cleaved at a conserved VEMD/VEVD residue during apoptosis. In addition to that, K18 posseses a second, K18 specific caspase-cleavage site at Asp396, which is an early event during apoptosis preceding the cleavage at the VEMD/VEVD motif (Oshima 2002; Marceau et al. 2007). The cleavage of human K18 at Asp396 can be monitored using the M30 antibody (Leers et al. 1999) and M30-Ab ELISA has become a useful serologic test for determining liver disease severity. For example, elevated serum M30 titers can distinguish simple steatosis from non-alcoholic steatohepatitis (Wieckowska et al. 2006) and predict several important prognostic parameters in patients with chronic hepatitis C infection (Bantel et al. 2004; Volkmann et al. 2006).

As another tool for detecting apoptotic keratin fragments, an antibody specific to the conserved K18/K19 cleavage site at Asp237 was recently generated (Tao et al. 2008). It detects both mouse and human K18/K19 fragments and appears to be more sensitive than the established Asp396-Ab (Tao et al. 2008). Measuring the serum levels of apoptosis-specific keratin fragments should also improve our understanding of chronic liver disease, where apoptotic cell death is an important pathogenic feature (Malhi et al. 2006).

In addition to that, monitoring the phosphorylation status of the circulating keratin fragments might be useful. Keratins undergo dynamic phosphorylation during mitosis, apoptosis and a variety of stress situations (Omary et al. 1998; Omary et al. 2006) and their in situ phosphorylation status is a marker of human liver disease progression (Toivola et al. 2004). However, it is currently unknown whether the phosphorylation status of the circulating keratin fragments correlates with the situation in situ.

\section{Hepatic phenotype in keratin-deficient transgenic animals}

The liver consists of different cell types with characteristic IF composition (Table 3; Omary et al. 2002). Adult hepatocytes are unique among simple epithelial cells in that they express exclusively $\mathrm{K} 8$ and $\mathrm{K} 18$, whereas other glandular epithelia exhibit a more complex keratin expression pattern (Omary et al. 2002; Ku et al. 2007). The hepatocytic keratin IF network is dense, particularly around bile canaliculi and at the cell periphery, and acts as cytoskeletal backbone to the functionally more dynamic and contractile actin microfilament system (Zatloukal et al. 2004). Biliary epithelial cells differ from hepatocytes by additional expression of keratin 7 and 19 (Omary et al. 2002; Zatloukal et al. 2004). Keratins in cholangiocytes, but not hepatocytes, exhibit polarized and compartment-specific expression pattern (Omary et al. 2002; Zatloukal et al. 2004). The biological significance of such an expression is enigmatic, but it may be related to polarity and secretory processes. Among nonepithelial cells, stellate cells express variable amounts of GFAP, desmin, vimentin, and nestin dependent on their activation status, localization, and other parameters (Table 3; Geerts 2001).

Studies in keratin knock-out mice revealed that the regular liver development does not require the presence of $\mathrm{K} 8$, $\mathrm{K} 18$, or $\mathrm{K} 19$ (Ku et al. 2007). However, K8/K18 knockout mice exhibited mild chronic hepatitis, hepatocyte fragility and were markedly more sensitive to a variety of stress conditions (Omary et al. 2002; Zatloukal et al. 2004; Ku et al. 2007). Furthermore, K8/K18 transgenic mice were developed, which over-express different single-amino-acid variants (Ku et al. 2007). Among them, the K18 R89C variant resulted in disruption of hepatocyte IF network and exhibited a phenotype reminiscent of the situation in $\mathrm{K} 8 / \mathrm{K} 18$ knockout mice (Ku et al. 1995, 1996). K18 R89C mice also

Table 3 IFs of liver cell populations

\begin{tabular}{ll}
\hline Cell type & IF composition \\
\hline Hepatocyte & $\mathrm{K} 8 / \mathrm{K} 18^{\mathrm{a}}$ \\
Oval cells & $\mathrm{K} 7 / \mathrm{K} 8 / \mathrm{K} 18 / \mathrm{K} 19$ \\
Cholangiocyte & $\mathrm{K} 7 / \mathrm{K} 8 / \mathrm{K} 18 / \mathrm{K} 19$ \\
Kupffer cell & Vimentin \\
Stellate cell & GFAP, Vimentin, Desmin, Nestin \\
Endothelial cell & Vimentin
\end{tabular}

Modified from Omary et al. (2002)

a During embryogenesis, hepatocytes also express variable levels of K19 (Vassy et al. 1997)

b Stellate cells represent a highly heterogeneous population with variable IF expression dependent on species, activation status of the cell, location within the hepatic lobe and many other parameters (Geerts 2001) 
predisposed to development of thioacetamide-induced liver fibrosis (Strnad et al. 2008). Ablations of different K8/K18 phosphorylation sites usually led to a somewhat milder phenotype which became apparent in stress situations, but not under basal conditions (Ku et al. 2007). For example, K18 S52A variant resulted in increased sensitivity to microcystin-LR-induced liver injury, whereas K8 S73A mice were predisposed to Fas-induced liver apoptosis (Ku et al. 1998; Ku and Omary 2006). The ablation of K18 S33 phosphorylation site, which regulates the binding to $14-3-3$ proteins, caused limited mitotic arrest and accumulation of abnormal mitotic figures after partial hepatectomy $(\mathrm{Ku}$ et al. 2002a).

In contrast, mice lacking K19 did not have an obvious liver phenotype (Tao et al. 2003), but surprisingly exhibited skeletal myopathy (Stone et al. 2007). GFAP/vimentinknockouts displayed compromised astrocytic function with attenuated reactive gliosis, but no obvious alteration in the in vitro activation of hepatic stellate cells despite the lack of IF network (Geerts et al. 2001; Pekny and Pekna 2004). However, in vivo studies are needed to conclusively address the fibrogenic potency of these transgenic mice.

\section{Keratin variants in liver disease}

The large body of evidence from animal studies showing the importance of $\mathrm{K} 8 / \mathrm{K} 18$ for liver homeostasis led to a search for keratin mutations in patients with liver diseases. Several K8/K18 variants were found to associate with the development of cryptogenic liver disease (Ku et al. 2001). In subsequent studies, K8/K18 were shown to represent susceptibility genes for development of end-stage liver disease of multiple etiologies (Ku et al. 2003a, 2005). In particular, biologically significant $\mathrm{K} 8 / \mathrm{K} 18$ variants were found in 44 of 467 liver explants (12.4\%), but only in 11 out of 349 analyzed blood bank donors, which were used as a control group $(P<0.0001$, prevalence OR3.8; 95\% CI $=2.1-$ 7). Furthermore, K8/K18 variants associate with liver fibrosis progression in patients with chronic hepatitis C (Strnad et al. 2006).

$\mathrm{K} 8 \mathrm{R} 340 \mathrm{H}$ represents the most common amino acid altering K8/K18 variant and it is the only one, which was significantly associated with development of end-stage liver disease (Ku et al. 2005). Larger studies are needed to analyze the pathological significance of the other less common K8/K18 variants (Ku et al. 2007).

In contrast to human association studies, experiments in K8/K18-deficient mice were shown to predispose mainly to acute liver injury (Ku et al. 2007). To address this issue, we recently analyzed a large cohort of patients with acute liver failure (ALF). K8/K18 variants were significantly more frequent in total ALF patient cohort $(46 / 345 ; 13.3 \%)$ and in patients with acetaminophen-induced ALF $(21 / 169 ; 12.4 \%)$ when compared to blood bank donors $(11 / 349 ; 3.7 \%$; $P<0.002$ for both comparisons). Among the single polymorphisms, the $\mathrm{K} 8 \mathrm{R} 340 \mathrm{H}$ variant was found at significantly higher frequencies in the whole ALF cohort as well as in the acetaminophen-induced ALF subgroup (frequency 6.6 and $7.1 \%$, respectively vs. $3.1 \%$ in the control group; $P<0.03$ for both comparisons). In addition, transgenic mice over-expressing K8 R340 variants displayed augmented acetaminophen-induced liver toxicity. In conclusion, K8/K18 are also susceptibility genes for development of ALF and K8/K18 variants may predispose to druginduced liver injury (Strnad et al., unpublished data).

Up to date, only one published study analyzed the polymorphisms in K19 gene and found no association between K19 variants and inflammatory bowel disease (Tao et al. 2007). Interestingly, we recently observed K19 G17S variant in three out of 190 patients with primary biliary cirrhosis, but none was found in control blood bank donors (200 samples; Zhong et al., unpublished data). However, larger studies are needed to address the importance of K19 in biliary diseases.

The human K8/K18 variants described above do not cause a particular liver disease per se, they just pose a risk factor for its development. This is different from the situation in stratified epithelia, where keratin mutations result in several monogenic keratin diseases (Lane and McLean 2004; Omary et al. 2004). This discrepancy may be caused either by the intrinsic difference between keratins of simple and stratified epithelia (Hutton et al. 1998) or by the different localization of the variants within the protein backbone. To that end, disease-causing keratin mutations in stratified epithelia are clustered in the highly conserved helix initiation and termination motif, whereas K8/K18 disease-predisposing variants are observed in more variable domains (Owens and Lane 2004; Omary et al. 2004; Ku et al. 2007).

The disturbance in cytoprotective function of keratins is the likely mechanisms by which $\mathrm{K} 8$ and $\mathrm{K} 18$ variants predispose to liver disorders. For example, K8/K18 are antiapoptotic proteins and this ability is hampered in keratindeficient animals (Oshima 2002; Ku and Omary 2006; Marceau et al. 2007; Ku et al. 2007). The ways of interaction between keratins and apoptosis are manifold. K8/K18 bind to several apoptotic proteins and type I keratins are established caspase substrates (Oshima 2002; Green et al. 2005; Marceau et al. 2007). In addition, K8/K18 serve as physiologic kinase substrates in vitro and in transgenic mice and an ablation of the K8 S73 phosphorylation site or introduction of the naturally occurring $\mathrm{K} 8 \mathrm{G} 61 \mathrm{C}$ variant leads to increased apoptosis through increased phosphorylation of pro-apoptotic proteins ( $\mathrm{Ku}$ et al. 2002b; Ku and Omary 2006). The keratin-mediated anti-apoptotic function may be highly relevant given the importance of apoptosis in liver 
disease and the pro-fibrogenic properties of elevated rate of apoptotic cell death (Friedman 2004; Malhi et al. 2006).

Keratins exhibit anti-oxidative properties, as they sequester oxidatively damaged proteins, and similarly, the K18 R89C variant primes the liver towards oxidative injury (Tao et al. 2005; Zhou et al. 2005). This keratin property might be helpful in attenuating both liver fibrosis and acetaminophen-induced liver injury (Parola and Robino 2001; Jaeschke et al. 2003). Keratins are also established stressinducible proteins, which are upregulated both in humans and mice under several, mainly cholestatic conditions (Fickert et al. 2002, 2003; Zatloukal et al. 2007; Ku et al. 2007; Strnad et al. 2008). Keratin variants may interfere with keratin upregulation or simply result in decreased keratin levels due to protein instability (as seen for K18 R89C variant in the liver; Ku et al. 1995).

The naturally occurring K8/K18 variants interfere with basic IF properties such as K8/K18 filament assembly and keratin solubility ( $\mathrm{Ku}$ et al. 2001; Owens et al. 2004; Ku et al. 2007). Due to altered protein conformation, some of them impair potentially cytoprotective keratin phosphorylation at adjacent residues (as seen in $\mathrm{K} 8 \mathrm{G} 61 \mathrm{C}$ and $\mathrm{K} 8$ G434S variant; $\mathrm{Ku}$ et al. 2005; Ku and Omary 2006).

$\mathrm{K} 8 / \mathrm{K} 18$ variants may also affect organelle function, as seen in K8 knockout mice, which exhibit altered mitochondrial shape, localization, and alterations in several mitochondrial proteins (Toivola et al. 2005).

Despite the various cytoprotective effects of keratins, their impact seems to be limited to certain conditions. For example, K18 R89C mice are predisposed to Fas but not TNF-induced apoptosis and the same mice develop more pronounced liver fibrosis after thioacetamide, but not after carbon tetrachloride injection (Ku et al. 2003b; Strnad et al. 2008). It is also unknown which one of the keratin-mediated effects is important in particular disease settings. The recently established transgenic mouse lines overexpressing the naturally occurring $\mathrm{K} 8 \mathrm{G} 61 \mathrm{C}$ and $\mathrm{R} 340 \mathrm{H}$ variants will likely offer valuable insights in this respect (Ku and Omary 2006; Zhou et al., unpublished data).

\section{Keratin network alteration in steatohepatitis of the alcoholic (ASH) and the non-alcoholic (NASH) type}

Steatohepatitis is characterized by hepatocyte "ballooning", that is, swelling and rounding with clearing of the cytoplasm, which prevails in the perivenular zone and is often associated with pericellular fibrosis, predominantly granulocytic inflammation ("satellitosis"), steatosis (usually of macrovesicular type), and cholestasis (Brunt 2004; Lefkowitch 2005). Ballooned cells are often associated with granular, rope- or clump-like cytoplasmic inclusions, called Mallory-Denk bodies (MDBs) (originally also designated alcoholic hyalin, which is, however, a misnomer since they are not specific for alcoholic etiology) together with derangement or even disappearance of the keratin IF cytoskeleton (Mallory 1911; Denk et al. 2000; Zatloukal et al. 2007; Fig. 1a, b). The disappearance of the keratin immunostaining in ballooned hepatocytes is reasonably specific for ASH and NASH, since it is not seen in ballooned cells of viral hepatitis or toxic damage and can therefore be used as an objective morphologic parameter in grading of steatohepatitis (Lackner et al. 2008). However, ballooning (with concomitant cytoskeletal alterations) and MDB formation are not entirely interchangeable since not all ballooned hepatocytes contain MDBs.

MDBs are typical morphological features of ASH and NASH, although NASH usually exhibits slightly less prominent MDBs than the ones seen in ASH (Brunt 2004; Zatloukal et al. 2007). MDBs can also be detected after intestinal bypass surgery for morbid obesity, in chronic cholestasis, particularly in late stages of primary biliary cirrhosis, Wilson disease and other types of copper toxicosis, various metabolic disturbances, and hepatocellular neoplasms (Müller et al. 2004; Zatloukal et al. 2007; Fig. 2). In contrast, MDBs have not been observed in the context of acute cholestasis, acute viral hepatitis and a variety of acute toxic or drug-induced liver diseases (Jensen and Gluud 1994, Zatloukal et al. 2007; Ku et al. 2007). However, even in potentially MDB-forming liver diseases, MDBs are found only in a subset of patients, partially (but not completely) depending on the sensitivity of the detection method used. For example, when using immunohistochemistry for keratin or ubiquitin, MDBs were found in about $70 \%$ of ASH cases in contrast to $40 \%$ seen in hematoxilineosin-stained sections (Ray 1987).

This suggests that MDBs require either a specific pathogenetic constellation or genetic predisposition for its formation, which is present only in a subset of patients.

Apart from MDBs, additional features may be observed in some chronic cholestatic conditions. For example, a low percentage of hepatocytes express keratin 7 and to a lesser extent keratin 19 which indicate that these cells acquire features of precursor cells which normally express keratin 8 , 18, 7, and 19 during regeneration (Van Eyken et al. 1988; Zatloukal et al. 2004). In idiopathic copper toxicosis and hepatocellular carcinoma, MDBs may coincide with another type of cytoplasmic inclusions, termed intracellular hyaline bodies (IHBs), which share several components with MDBs, but do not contain keratins (Stumptner et al. 1999; Denk et al. 2006).

The ease of MDB detection makes them attractive morphologic markers. However, correlation between the clinical disease manifestation/progression on one side and hepatocyte ballooning with MDB formation on the other is imperfect. For example, patients with severe clinical 

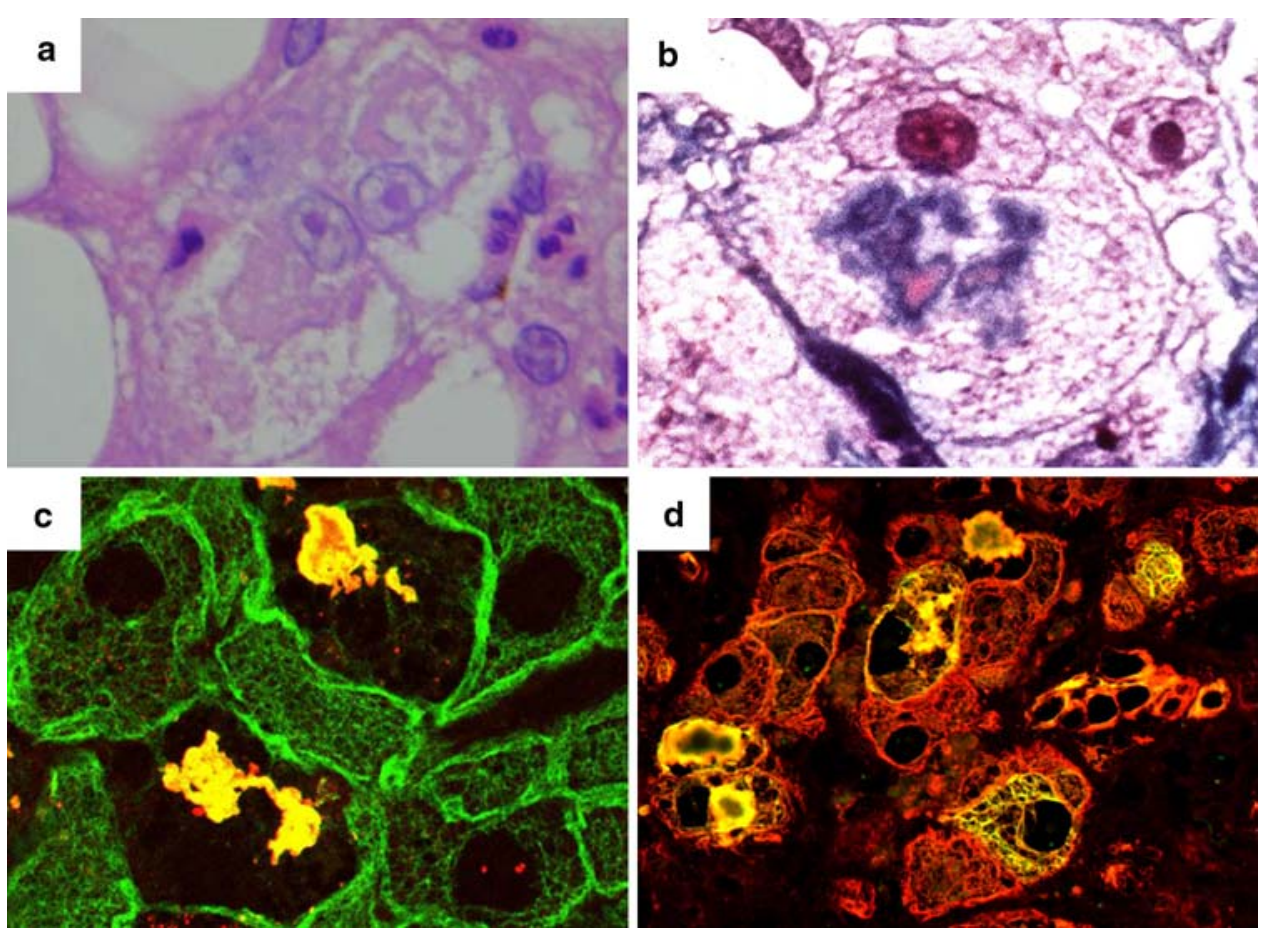

Fig. 1 MDBs are readily detected by different methods. In clinical routine, MDBs are usually detected as eosinophilic aggregates in standard hematoxylin and eosin stained sections (a). After chromotrope aniline blue staining, MDBs appear as blue structures, often with red center (b). Immunofluorescence or immunohistochemical staining represents a more sensitive method for MDB detection than conventional histological stainings, but is strongly dependent on the antibody used

as well as the staining protocol. MDBs can be reliably detected with antibodies against K8/K18 [green and red channel in (c) and (d), respectively] or p62 [red channel in (c)], whereas only some MDBs stain with antibodies to phosphorylated keratins such as K8 pS431 antibody [green channel in (d)]. In both immunofluorescence pictures, MDBs are seen as yellow structure due to co-localization of both visualized epitopes

Fig. 2 MDBs are seen in various human liver diseases. Immunohistochemical staining with p62 antibody visualizes the presence of multiple irregularly shaped aggregates in patients with alcoholic steatohepatitis (a), non-alcoholic steatohepatitis (b), Indian childhood cirrhosis and (c), idiopathic copper toxicosis $(\mathbf{d})$
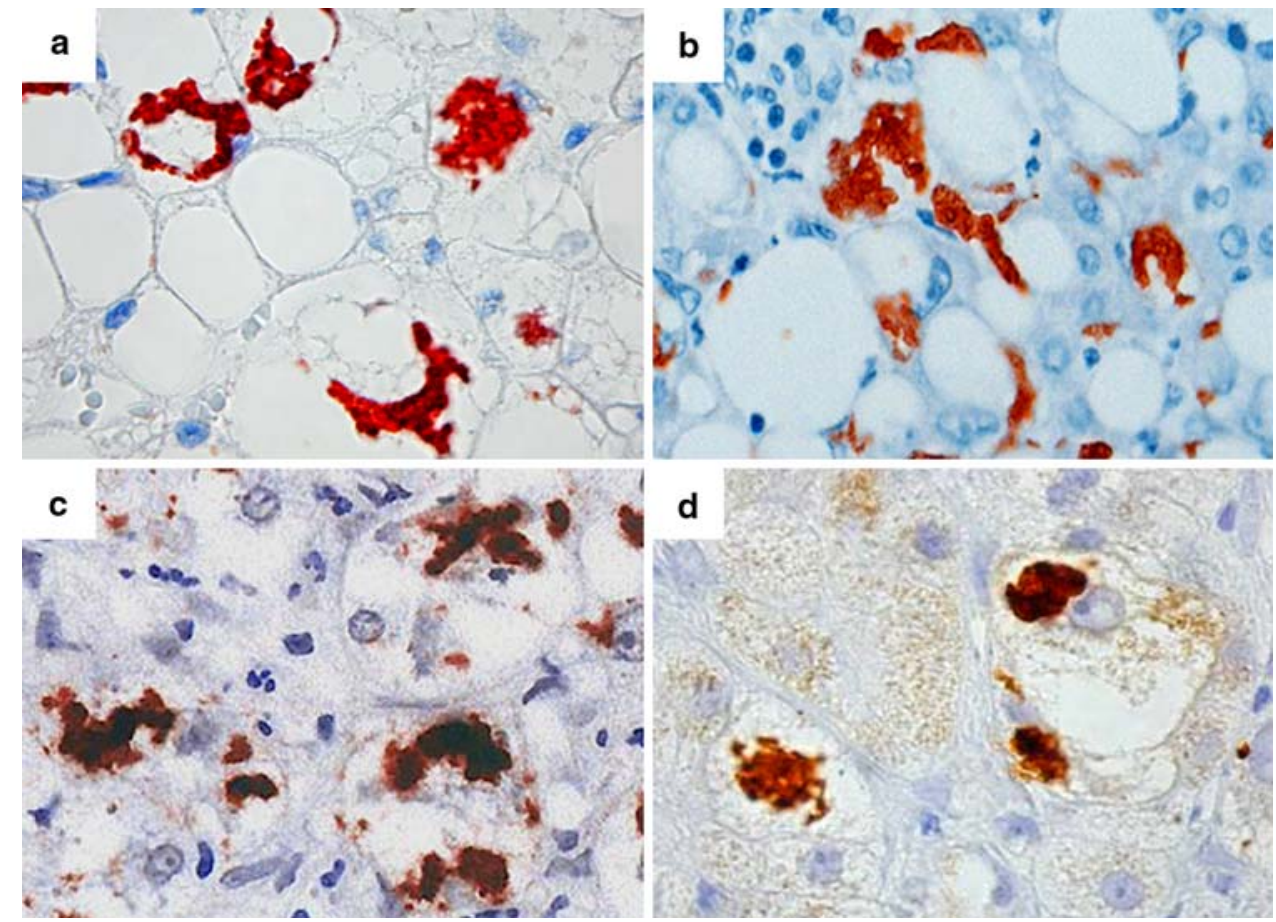
symptoms of ASH sometimes show only moderate histopathological alterations with few or no MDBs, whereas patients with pronounced histological alterations do not necessarily exhibit significant clinical and laboratory abnormalities (Zatloukal et al. 2007). Despite that, controlled clinical-pathologic studies comparing NASH patients with ambulatory and hospitalized alcoholics revealed that hepatocellular damage, presence of MDBs, inflammation, and fibrosis collectively correlated with disease severity (Cortez-Pinto et al. 2003). Also in other studies, hepatocellular ballooning and MDB formation was positively correlated with disease progression, development of fibrosis, and cirrhosis and liver-related mortality (Orrego et al. 1987; Matteoni et al. 1999; Gramlich et al. 2004; Mendler et al. 2005).

\section{Morphology and composition of MDBs}

MDBs are irregularly shaped, usually dense cytoplasmic inclusions of different sizes (Mallory 1911). Small MDBs arise in association with IF bundles throughout the cytoplasm, whereas larger MDBs are often seen in the perinuclear region (Denk et al. 2000; Zatloukal et al. 2007; Ku et al. 2007). Ultrastructurally, they usually consist of haphazardly arranged filamentous rods, approximately 10 $15 \mathrm{~nm}$ in diameter, covered by a fuzzy coat (designated as type II by Yokoo et al. 1972). In addition, MDBs with an electron dense granular to amorphous center (designated type 3) are seen predominantly in older inclusions, and filaments in parallel arrangement were also described (designated as type I) but seem to be exceedingly rare (Yokoo et al. 1972). Keratins 8 and 18, sequestosome 1/p62 (p62) and ubiquitin are major, and low and high molecular weight heat shock proteins (HSP 70, HSP 25), but also proteins of the protein degradation machinery, are minor constituents (Denk et al. 2000; Riley et al. 2002, 2003; Zatloukal et al. 2007; Ku et al. 2007; Figs. 1c, d; Fig. 2). Keratins 7, 19, and 20 have also occasionally been detected (Cadrin et al. 1990; Dinges et al. 1992). The K8/K18 within MDBs exhibit increased $\beta$-sheet structure (Cadrin et al. 1991; Kachi et al. 1993), are hyperphosphorylated, partially degraded and cross-linked (Hazan et al. 1986; Zatloukal et al. 1992; Cadrin et al. 1995; Stumptner et al. 2000; Fig. 1d). The list of MDB components is likely to grow since, in addition to intrinsic components, proteins non-specifically incorporated in the aggregate have to be expected.

\section{Pathogenesis of MDBs}

Studies on MDB formation and composition are greatly enhanced by the availability of animal models. MDBs can be induced under standardized conditions and their fate followed in mouse liver by chronic griseofulvin or 3,5-diethoxycarbonyl-1,4-dihydrocollidine (DDC) administration (Denk et al. 1975; Yokoo et al. 1982; Denk et al. 2000; Zatloukal et al. 2004, 2007; Fig. 3c, d).

In patients, MDB formation is usually a chronic process requiring several years of alcohol intoxication or metabolic imbalance, that is, in association with the metabolic syndrome, Wilson disease, other metabolic disorders, and chronic cholestasis. An exception is idiopathic copper toxicosis of children in which end stage liver disease associated with MDB formation occurs at very early age (Müller et al. 2004; Zatloukal et al. 2007). Surprisingly, in alcoholics recovered from ASH, an alcohol excess may almost instantaneously lead to MDB recurrence, a situation which has been compared to an immunologic response and termed "toxic memory" (Jensen and Gluud 1994; Denk et al. 2000). The animal model of MDB formation does not only reproduce the structural and morphological features seen in humans, but also the phenomenon of "toxic memory" (Fig. 3; Denk et al. 2000; Zatloukal et al. 2004, 2007). To induce MDBs in mice, griseofulvin or DDC is usually fed for 2-3 months. MDB formation in mice is reversible, since MDBs disappear after recovery on standard diet for 1 month. However, after rechallenge of the recovered ("primed") animals, MDBs reappear within a few days (Denk et al. 2000; Zatloukal et al. 2004, 2007). Rapid MDBs formation in primed mice is rather non-specific, since it can be triggered by a variety of stress conditions including colchicine (but not by lumicolchicine), bile acids, bile duct ligation, several other toxins, and proteasome inhibitors which were unable to induce MDBs in the naïve animal (Zatloukal et al. 2007, and references therein). The reasons for this phenomenon are as yet unclear but point to a final common pathway activated by the trigger.

The availability of cellular and animal models of MDB formation led to valuable insights into the mechanism of MDB formation. Several pathogenic mechanisms were implicated in this process (Fig. 4; Dobson 2004):

1. Enhanced oxidative stress

2. Disproportional K8/K18 expression together with keratin modifications

3. Chaperone dysfunction

4. Elevated p62 levels

5. Insufficient protein degradation

Ad 1. The MDB-inducing conditions both in humans and mice cause elevated levels of oxidative stress (Tephly et al. 1981; Mehta et al. 2002; Dey and Cederbaum 2006; Farrell and Larter 2006) and MDBs themselves were shown to contain misfolded keratins with increased $\beta$-sheet formation (Cadrin et al. 1991; Kachi et al. 1993). Recent animal studies highlight the importance of altered methyl group metabolism and mitochondrial stress in this process ( $\mathrm{Li}$ et al. 2008; 
Fig. 3 MDBs formed in DDCfed animals resemble inclusion bodies observed in human diseases. Liver sections were double labeled with antibodies to K8/K18 (green) and p62 (red). Samples from mouse fed DDC for 12 weeks (d) and from a patient with alcoholic steatohepatitis (b) exhibit multiple irregularly shaped inclusion bodies, which appear yellow due to presence of both epitopes. In contrast, control human (a) and mouse liver (c) display an unaffected keratin network with no apparent p62 staining. Note that DDC feeding leads to deposition of protoporphyrin, which can be seen as occasional blue pigment in $(\mathbf{d})$
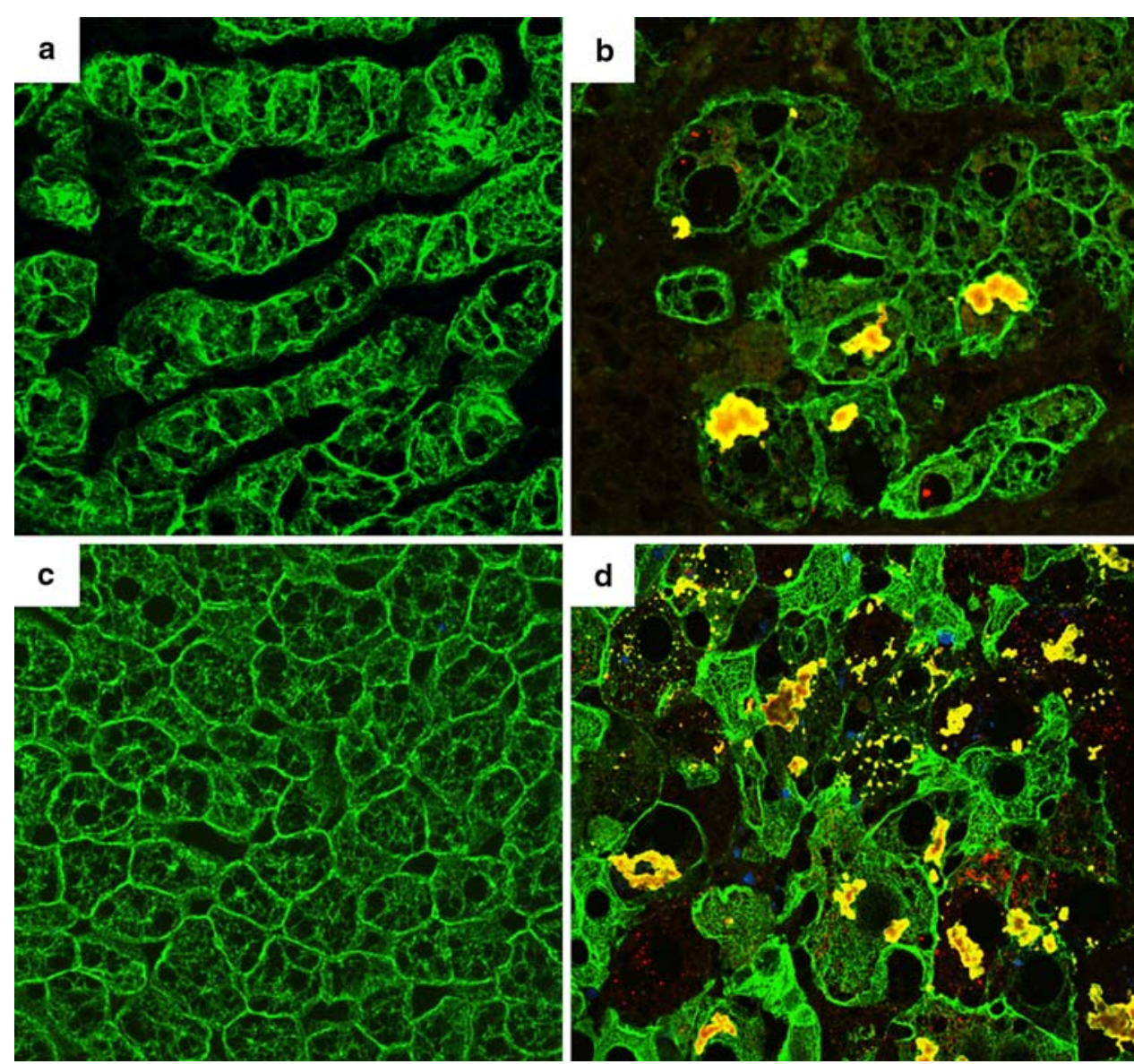

Zatloukal et al., unpublished data). During DDC detoxification, N-methylprotoporphyrin is formed through transfer of a methyl group to heme moieties (Tephly et al. 1981). N-methylprotoporphyrin subsequently acts as a potent inhibitor of ferrochelatase, thereby causing porphyria (Tephly et al. 1980). Accordingly, MDB formation and DDC effects can be effectively attenuated by feeding S-adenosylmethionine, that is a compound involved in methyl group transfer (Li et al. 2008). This is reminiscent of the situation in ASH, which is also associated with disrupted methyl group metabolism (Schalinske and Nieman 2005).

DDC targets mitochondria, where it reacts with cytochrome P450 (Marks et al. 1985). An unbiased microarray analysis identified cytochrome P450 (Cyp) 2a5 as a major gene induced both after DDC exposure and particularly after DDC re-challenge. Moreover, Cyp2e5 overexpression spacially coincides with MDB formation (Zatloukal et al., unpublished data). Cyp2a5 is a "leaky" cytochrome which produces reactive oxygen species (Lewis et al. 1989). In that sense, it resembles human Cyp2E1, which was implicated as a source of oxidative stress in the pathogenesis of ASH and NASH (Villeneuve and Pichette 2004).

To address the role of mitochondrial stress in MDB formation, we re-fed DDC-primed mice with DDC alone or in combination with the mitochondria-targeted antioxidant mito Q (Smith et al. 2003). Mito Q co-administration attenuated both MDB formation and DDC-induced liver damage. Therefore, mitochondrial oxidative stress seems to be involved in MDB formation in mice which is in good concordance to the mitochondrial dysfunction seen both in ASH and NASH patients (Pessayre 2007; Mantena et al. 2008; Zatloukal et al., unpublished data).

Ad 2. Keratins are major constituents of MDBs and both altered K8/K18 expression and keratin modification seems to affect MDB formation (Zatloukal et al. 2007; Ku et al. 2007). Griseofulvin/DDC feeding leads to rapid induction of K8/K18 expression with disproportional K8 > K18 levels (Denk et al. 2000). The elevated K8/K18 ratio is crucial for MDB formation as shown in K18-knockout and K8 overexpressing animals, who are predisposed to MDB formation already upon short exposure to DDC and even form MDBs spontaneously during aging (Magin et al. 1998; Nakamichi et al. 2005). Accordingly, K8-null or K18 overexpressing mice are resistant to MDB formation and the protective function of K18 is not affected by its phosphorylation status or mutation (Zatloukal et al. 2000; Harada et al. 2007). However, the exclusive MDB inducing property of $\mathrm{K} 8$ in vivo cannot be reproduced in vitro, where aggregates resem- 


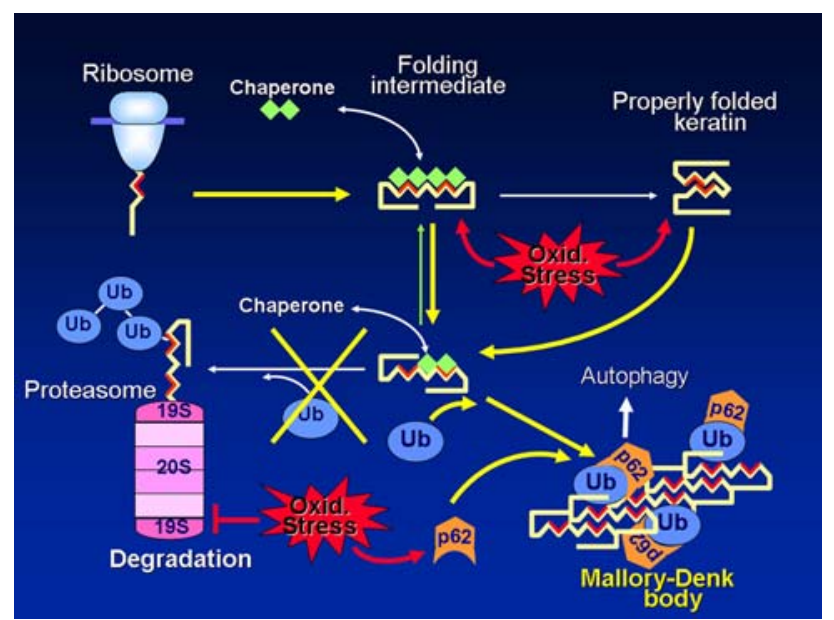

Fig. 4 MDBs formation results from a complex interplay of several contributing factors. Since the cytoplasm represents a hydrophilic milieu, all exposed hydrophobic molecules (depicted by red stretches within the protein) are predisposed to aggregation. Properly folded proteins usually hide their hydrophobic stretches inside, but these get exposed in nascent protein chains or after proteins become misfolded as a consequence of oxidative stress. Chaperones bind to these hydrophobic residues and facilitate protein refolding. Alternatively, damaged proteins become polyubiquitinated and degraded either by the proteasomal or autophagic system. MDB-causing agents typically generate extensive amount of oxidative stress with increased protein misfolding. In addition, chaperone levels are downregulated and/or chaperone function is compromised. Dysbalanced K8/K18 expression precedes MDB formation, likely increases keratin misfolding and predisposes to posttranslational modifications, which may interfere with keratin refolding and/or repair. Accumulated misfolded proteins are sequestered as inclusions through the action of p62. p62 also shuttles polyubiquitinated proteins to degradative machineries. However, proteasomal degradation might be impaired by oxidative stress, may not be able to digest highly cross-linked protein species or might simply be overwhelmed by the excessive supply. On the other hand, autophagy is upregulated during MDB formation in mice and additional stimulation of autophagy attenuates MDB formation in certain conditions. Of note, supplementation of S-adenosylmethionine or mitochondrially targeted antioxidants effectively diminishes MDB formation, thereby pointing to a central role of oxidative stress in MDB generation

bling MDBs can also be produced by transfection of K18 (Nakamichi et al. 2002; Stumptner et al. 2007).

Among posttranslational modifications, MDB formation is associated with $\mathrm{K} 8$ hyperphosphorylation and transamidation (Zatloukal et al. 1992; Stumptner et al. 2000). In a recent study, ablation of K8 S73 phosphorylation site in transgenic mice resulted in diminished MDB formation after DDC exposure (Harada et al., unpublished results). Several potential mechanisms might be responsible for this observation. K8 S73 is a well-known p38 kinase target site and p38 up-regulation induces keratin network reorganization with subsequent granule formation (Ku et al. 2002b; Wöll et al. 2007). P38 kinase-induced keratin network reorganization might be a necessary prerequisite for MDB formation, since p38 kinase inhibition prevented MDB formation in vitro (Nan et al. 2006). Alternatively, K8 hyperphosphorylation may induce MDB formation through inhibition of $\mathrm{K} 8$ degradation, which results in increased $\mathrm{K} 8 / \mathrm{K} 18$ ratio (Ku and Omary 2000).

MDBs contain highly cross-linked keratins and the ablation of tissue transglutaminase effectively inhibits DDCinduced MDB formation (Zatloukal et al. 1992; Strnad et al. 2007). Since K8 is a much better in vitro transglutaminase substrate than K18 and highly cross-linked proteins found in MDB-forming mice contain K8, but not K18, it was suggested that excessive $\mathrm{K} 8$ gets preferentially transamidated and acts as a nucleus for MDB formation. This is supported by studies in transgenic mice, where $\mathrm{K} 8$ overexpression accelerates and K18 excess inhibits not only MDB, but also cross-link formation (Strnad et al. 2007).

Ad 3. MDBs were shown to contain misfolded keratins (Cadrin et al. 1991, Kachi et al. 1993). The protein misfolding is usually counteracted by the reparative function of chaperones (Ross and Poirier 2004; Macario and Conway de Macario 2005; Bukau et al. 2006), however, DDC feeding is associated with diminished chaperone expression, persistent chaperone modifications and impairment of chaperone function (Strnad et al. submitted). Similarly, chaperone function is impaired in a rat model of chronic alcoholic liver disease (Carbone et al. 2005).

Ad 4. P62 is a stress-inducible protein with multiple functions which is a constituent of multiple inclusion bodies termed sequestosomes (Shin 1998; Kuusisto et al. 2001; Zatloukal et al. 2002; Moscat et al. 2007). It binds proteins polyubiquitinated at lysine 63 and shuttles them for proteasomal or autophagic degradation (Vadlamudi et al. 1996; Bjorkoy et al. 2005; Seibenhener et al. 2004; Wooten et al. 2008). p62 has been shown to enhance aggregate formation (Donaldson et al. 2003; Wang et al. 2005; Komatsu et al. 2007; Gal et al. 2007; Nezis et al. 2008). p62 action is beneficial under normal conditions, since it prevents accumulation of abnormal proteins (Bjorkoy et al. 2005; Ramesh Babu et al. 2008), but may become harmful when protein degradation is inhibited (Komatsu et al. 2007).

There are several lines of evidence implicating p62 (containing the ubiquitin binding site) in MDB formation. In cell culture experiments, protein aggregates resembling MDBs formed only after p62 co-transfection, but not when $\mathrm{K} 8, \mathrm{~K} 18$, and ubiquitin were transfected alone or in combination (Stumptner et al. 2007). Furthermore, p62 was rapidly induced in DDC-fed mice with p62-containing aggregates preceding the formation of MDBs (Stumptner et al. 2002). Furthermore, p62 inhibition attenuated, whereas p62 overexpression enhanced MDB formation in DDC-primed hepatocytes (Nan et al. 2006).

Ad 5. Accumulation of protein aggregates, as seen during MDB formation, is counteracted by proteasomal or autophagic degradation (Glickman and Ciechanover 2002; Williams et al. 2006) and both degradation machineries are 
active in the liver. For example, conditional knock-out of the autophagy-related gene 7 (Atg7) leads to development of ubiquitin-positive inclusions in hepatocytes (Komatsu et al. 2005). Similarly, proteasomes seem to interact with MDBs and inhibition of proteasomal degradation leads to formation of MDB-like structures both in vitro and in DDC-primed mice (Harada et al. 2003; Bardag-Gorce et al. 2002; Riley et al. 2002; French et al. 2001). Furthermore, autophagic degradation is upregulated in DDC-fed mice and its further stimulation with rapamycin attenuates spontaneous MDB formation in $\mathrm{K} 8$ overexpressing mice (Harada et al. 2008).

In contrast, MDB formation might be facilitated by proteasomal impairment, since MDBs are preferentially seen in proteasome-depleted hepatocytes (Bardag-Gorce et al. 2001). In addition, an aberrant form of ubiquitin, termed [UBB + 1] arising as a consequence of molecular misreading, is observed in MDBs and may inhibit proteasomal function (McPhaul et al. 2002; Lindsten et al. 2002). Similarly, alcohol and aging, both potential inducers of MDBs can be associated with decreased proteasome function (Hayashi and Goto 1998; Fataccioli et al. 1999).

However, aggregate formation must not always be caused by a general inhibition in protein degradation. The degradative capacity may simply be overwhelmed by increased amounts of misfolded proteins. Alternatively, certain proteins may not be easily degradable, such as proteins with long polyglutamine stretches (Venkatraman et al. 2004). The latter scenario may apply to DDC-fed mice, which exhibit an accumulation of ubiquitinated protein only in the highly insoluble protein fraction (Strnad et al. 2007). This fraction is characterized by highly cross-linked protein species generated through extensive transamidation, which may make them resistant to proteolytic degradation (Strnad et al. 2007).

\section{Pathologic significance of MDBs}

In principle, cytoplasmic protein aggregates can be beneficial, detrimental or inert depending on the context. In many pathologic situations aggregation seems to be a protective response if the first lines of defense, that is, refolding and degradation, fail by sequestration of potentially harmful proteins (Arrasate et al. 2004; Bodner et al. 2006). On the other hand, large protein aggregates can be detrimental either by mechanical interference with cellular transport processes (e.g., shown with microtubule-dependent transport in neurons), deprivation of the cell of vital components by aggregation or coaggregation and by overwhelming/ inhibiting the capacity of the chaperone system and/or the protein degradation machinery by indigestible material (Alonso et al. 1997; Stenoien et al. 1999; Suhr et al. 2001;
Bence et al. 2001; Lee et al. 2004; Grune et al. 2004). It can be expected, therefore, that in different cell systems and pathologic conditions inclusion bodies differ regarding their cellular effects and consequences. MDBs per se do not seem to compromise the viability of transfected tissue culture cells (Stumptner et al. 2007) or hepatocytes in vivo, who even exhibit an activated phenotype (Denk et al. 2000). Further studies are needed to definitely characterize the molecular consequences of MDB formation.

\section{References}

Alonso AD, Grundke-Iqbal I, Barra HS, Iqbal K (1997) Abnormal phosphorylation of tau and the mechanism of Alzheimer neurofibrillary degeneration: sequestration of microtubule-associated proteins 1 and 2 and the disassembly of microtubules by the abnormal tau. Proc Natl Acad Sci USA 94:298-303

Arrasate M, Mitra S, Schweitzer ES, Segal MR, Finkbeiner S (2004) Inclusion body formation reduces levels of mutant huntingtin and the risk of neuronal death. Nature 431:805-810

Bantel H, Lugering A, Heidemann J, Volkmann X, Poremba C, Strassburg CP, Manns MP, Schulze-Osthoff K (2004) Detection of apoptotic caspase activation in sera from patients with chronic $\mathrm{HCV}$ infection is associated with fibrotic liver injury. Hepatology 40:1078-1087

Barak V, Goike H, Panaretakis KW, Einarsson R (2004) Clinical utility of cytokeratins as tumor markers. Clin Biochem 37:529-540

Bardag-Gorce F, French BA, Lue YH, Nguyen V, Wan YJ, French SW (2001) Mallory bodies formed in proteasome-depleted hepatocytes: an immunohistochemical study. Exp Mol Pathol 70:7-18

Bardag-Gorce F, van Leeuwen FW, Nguyen V, French BA, Li J, Riley N, McPhaul LW, Lue YH, French SW (2002) The role of the ubiquitin-proteasome pathway in the formation of Mallory bodies. Exp Mol Pathol 73:75-83

Bence NF, Sampat RM, Kopito RR (2001) Impairment of the ubiquitin-proteasome system by protein aggregation. Science 292:1552-1555

Bershadsky AD, Vasiliev JM (1988) Cytoskeleton. In: Cellular Organelles, Plenum Press, New York, pp 133-154

Bjorkoy G, Lamark T, Brech A, Outzen H, Perander M, Overvatn A, Stenmark H, Johansen T (2005) P62/SQSTM1 forms protein aggregates degraded by autophagy and has a protective effect on huntingtin-induced cell death. J Cell Biol 171:603-614

Bodner RA, Outeiro TF, Altmann S, Maxwell MM, Cho SH, Hyman BT, McLean PJ, Young AB, Housman DE, Kazantsev AG (2006) Pharmacological promotion of inclusion formation: a therapeutic approach for Huntington's and Parkinson's diseases. Proc Natl Acad Sci U S A 103:4246-4251

Brunt EM (2004) Nonalcoholic steatohepatitis. Semin Liver Dis 24:3-20

Bukau B, Weissman J, Horwich A (2006) Molecular chaperones and protein quality control. Cell 125:443-451

Cadrin M, Kawahara H, Ohta M, Katsuma Y, Marceau N, French SW (1990) Mallory bodies in hepatomas and hyperplastic nodules: in vitro and in vivo studies. Prog Clin Biol Res 331:231-248

Cadrin M, French SW, Wong PT (1991) Alteration in molecular structure of cytoskeleton proteins in griseofulvin-treated mouse liver: a pressure tuning infrared spectroscopy study. Exp Mol Pathol 55:170-179

Cadrin M, Hovington H, Marceau N, McFarlane-Anderson N (1995) Early perturbations in keratin and actin gene expression and fibrillar organisation in griseofulvin-fed mouse liver. J Hepatol 33:199-207 
Cairns NJ, Lee VM, Trojanowski JQ (2004) The cytoskeleton in neurodegenerative diseases. J Pathol 204:438-449

Carbone DL, Doorn JA, Kiebler Z, Ickes BR, Petersen DR (2005) Modification of heat shock protein 90 by 4-hydroxynonenal in a rat model of chronic alcoholic liver disease. J Pharmacol Exp Ther 315:8-15

Coulombe PA, Omary MB (2002) "Hard" and "soft" principles defining the structure, function and regulation of keratin intermediate filaments. Curr Opin Cell Biol 14:110-122

Cortez-Pinto H, Baptista A, Camilo ME, De Moura MC (2003) Nonalcoholic steatohepatitis-a long-term follow-up study: comparison with alcoholic hepatitis in ambulatory and hospitalized patients. Dig Dis Sci 48:1909-1913

Dechat T, Pfleghaar K, Sengupta K, Shimi T, Shumaker DK, Solimando L, Goldman RD (2008) Nuclear lamins: major factors in the structural organization and function of the nucleus and chromatin. Genes Dev 22:832-853

Denk H, Gschnait F, Wolff K (1975) Hepatocellular hyalin (Mallory bodies) in long term griseofulvin-treated mice. A new experimental model for the study of hyalin formation. Lab Invest 32:773776

Denk H, Stumptner C, Zatloukal K (2000) Mallory bodies - revisited. J Hepatol 32:689-702

Denk H, Stumptner C, Fuchsbichler A, Müller T, Farr GH, Müller W, Terracciano L, Zatloukal K (2006) Are the Mallory bodies and intracellular hyaline bodies in neoplastic and non-neoplastic hepatocytes related? J Pathol 208:653-661

Dey A, Cederbaum AI (2006) Alcohol and oxidative liver injury. Hepatology 43:S63-S74

Dinges HP, Zatloukal K, Denk H, Smolle J, Mair S (1992) Alcoholic liver disease. Parenchyma to stroma relationship in fibrosis and cirrhosis as revealed by three-dimensional reconstruction and immunohistochemistry. Am J Pathol 141:69-83

Dobson CM (2004) Principles of protein folding, misfolding and aggregation. Semin Cell Dev Biol 15:3-16

Donaldson KM, Li W, Ching KA, Batalov S, Tsai CC, Joazeiro CA (2003) Ubiquitin-mediated sequestration of normal cellular proteins into polyglutamine aggregates. Proc Natl Acad Sci USA 100:8892-8897

Farrell GC, Larter CZ (2006) Nonalcoholic fatty liver disease: from steatosis to cirrhosis. Hepatology 43:S99-S112

Fataccioli V, Andraud M, Gentil M, French SW, Rouach H (1999) Effects of chronic ethanol administration on rat liver proteasome activities: relationship with oxidative stress. Hepatology 29:14-20

Fickert P, Trauner M, Fuchsbichler A, Stumptner C, Zatoukal K, Denk H (2002) Bile acid-induced Mallory body formation in drugprimed mouse liver. Am J Pathol 161:2019-2026

Fickert P, Trauner M, Fuchsbichler A, Stumptner C, Zatloukal K, Denk $\mathrm{H}$ (2003) Mallory body formation in primary biliary cirrhosis is associated with increased amounts and abnormal phosphorylation and ubiquitination of cytokeratins. J Hepatol 38:387-394

French BA, van Leeuwen F, Riley NE, Yuan QX, Bardag-Gorce F, Gaal K, Lue YH, Marceau N, French SW (2001) Aggresome formation in liver cells in response to different toxic mechanisms: role of the ubiquitin-proteasome pathway and the frameshift mutant of ubiquitin. Exp Mol Pathol 71:241-246

Friedman SL (2004) Mechanisms of disease: mechanisms of hepatic fibrosis and therapeutic implications. Nat Clin Pract Gastroenterol Hepatol 1:98-105

Gal J, Ström AL, Kilty R, Zhang F, Zhu H (2007) p62 accumulates and enhances aggregate formation in model systems of familial amyotrophic lateral sclerosis. J Biol Chem 282:11068-11077

Geerts A (2001) History, heterogeneity, developmental biology, and functions of quiescent hepatic stellate cells. Semin Liver Dis 21:311-335
Geerts A, Eliasson C, Niki T, Wielant A, Vaeyens F, Pekny M (2001) Formation of normal desmin intermediate filaments in mouse hepatic stellate cells requires vimentin. Hepatology 33:177-188

Glickman MH, Ciechanover A (2002) The ubiquitin-proteasome proteolytic pathway: destruction for the sake of construction. Physiol Rev 82:373-428

Goldman RD, Grin B, Mendez MG, Kuczmarski ER (2008) Intermediate filaments: versatile building blocks of cell structure. Curr Opin Cell Biol 20:28-34

Godsel LM, Hobbs RP, Green KJ (2008) Intermediate filament assembly: dynamics to disease. Trends Cell Biol 18:28-37

Goebel HH (1998) Congenital myopathies with inclusion bodies: a brief review. Neuromuscul Disord 8:162-168

Gonzalez-Quintela A, García J, Campos J, Perez LF, Alende MR, Otero E, Abdulkader I, Tomé S (2006a) Serum cytokeratins in alcoholic liver disease: contrasting levels of cytokeratin-18 and cytokeratin-19. Alcohol 38:45-49

Gonzalez-Quintela A, Mallo N, Mella C, Campos J, Perez LF, LopezRodriguez R, Tome S, Otero E (2006b) Serum levels of cytokeratin-18 (tissue polypeptide-specific antigen) in liver diseases. Liver Int 26:1217-1224

Gramlich T, Kleiner DE, McCullough AJ, Matteoni CA, Boparai N, Younossi ZM (2004) Pathologic features associated with fibrosis in nonalcoholic fatty liver disease. Hum Pathol 35:196-199

Green KJ, Böhringer M, Gocken T, Jones JC (2005) Intermediate filament associated proteins. Adv Protein Chem 70:143-202

Grune T, Jung T, Merker K, Davies KJ (2004) Decreased proteolysis caused by protein aggregates, inclusion bodies, plaques, lipofuscin, ceroid, and "aggresomes" during oxidative stress, aging, and disease. Int J Biochem Cell Biol 36:2519-2530

Harada M, Kumemura H, Omary MB, Kawaguchi T, Maeyama N, Hanada S, Taniguchi E, Koga H, Suganuma T, Ueno T, Sata M (2003) Proteasome inhibition induces inclusion bodies associated with intermediate filaments and fragmentation of the Golgi apparatus. Exp Cell Res 288:60-69

Harada M, Strnad P, Resurreccion E, Ku NO, Omary MB (2007) Keratin 18 overexpression but not phosphorylation or filament organization blocks mouse Mallory body formation. Hepatology 45:88-96

Harada M, Hanada S, Toivola DM, Ghori N, Omary MB (2008) Autophagy activation by rapamycin eliminates mouse MalloryDenk bodies and blocks their proteasome inhibitor-mediated formation. Hepatology in press

Hatzfeld M, Franke WW (1985) Pair formation and promiscuity of cytokeratins: formation in vitro of heterotypic complexes and intermediate-sized filaments by homologous and heterologous recombinations of purified polypeptides. J Cell Biol 101:1826-1841

Hayashi T, Goto S (1998) Age-related changes in the 20S and 26S proteasome activities in the liver of male F344 rats. Mech Ageing Dev 102:55-66

Hazan R, Denk H, Franke WW, Lackinger E, Schiller DL (1986) Change of cytokeratin organization during development of Mallory bodies as revealed by a monoclonal antibody. Lab Invest 54:543-553

Herrmann H, Bär H, Kreplak L, Strelkov SV, Aebi U (2007) Intermediate filaments: from cell architecture to nanomechanics. Nat Rev Mol Cell Biol 8:562-573

Hutton E, Paladini RD, Yu QC, Yen M, Coulombe PA, Fuchs E (1998) Functional differences between keratins of stratified and simple epithelia. J Cell Biol 143:487-499

Jaeschke H, Knight TR, Bajt ML (2003) The role of oxidant stress and reactive nitrogen species in acetaminophen hepatotoxicity. Toxicol Lett 144:279-288

Jensen K, Gluud C (1994) The Mallory body: morphological, clinical and experimental studies (Part 1 of a literature survey). Hepatology 20:1061-1077 
Kachi K, Wong PT, French SW (1993) Molecular structural changes in Mallory body proteins in human and mouse livers: an infrared spectroscopy study Exp Mol Pathol 59:197-210

Kim S, Coulombe PA (2007) Intermediate filament scaffolds fulfill mechanical, organizational, and signaling functions in the cytoplasm. Genes Dev 21:1581-1597

Komatsu M, Waguri S, Ueno T, Iwata J, Murata S, Tanida I, Ezaki J, Mizushima N, Ohsumi Y, Uchiyama Y, Kominami E, Tanaka $\mathrm{K}$, Chiba T (2005) Impairment of starvation-induced and constitutive autophagy in Atg7-deficient mice. J Cell Biol 169:425434

Komatsu M, Waguri S, Koike M, Sou YS, Ueno T, Hara T, Mizushima N, Iwata J, Ezaki J, Murata S, Hamazaki J, Nishito Y, Iemura S, Natsume T, Yanagawa T, Uwayama J, Warabi E, Yoshida H, Ishii T, Kobayashi A, Yamamoto M, Yue Z, Uchiyama Y, Kominami E, Tanaka K (2007) Homeostatic levels of p62 control cytoplasmic inclusion body formation in autophagy-deficient mice. Cell 131:1149-1163

Ku NO, Michie S, Oshima RG, Omary MB (1995) Chronic hepatitis, hepatocyte fragility, and increased soluble phosphoglycokeratins in transgenic mice expressing a keratin 18 conserved arginine mutant. J Cell Biol 131:1303-1314

Ku NO, Michie SA, Soetikno RM, Resurreccion EZ, Broome RL, Oshima RG, Omary MB (1996) Susceptibility to hepatotoxicity in transgenic mice that express a dominant-negative human keratin 18 mutant. J Clin Invest 98:1034-1046

Ku NO, Michie SA, Soetikno RM, Resurreccion EZ, Broome RL, Omary MB (1998) Mutation of a major keratin phosphorylation site predisposes to hepatotoxic injury in transgenic mice. J Cell Biol 143:2023-2032

Ku N-O, Zhou X, Toivola DM, Omary MB (1999) The cytoskeleton of digestive epithelia in health and disease. Am $\mathrm{J}$ Physiol 277:G1108-G1137

$\mathrm{Ku}$ NO, Omary MB (2000) Keratins turn over by ubiquitination in a phosphorylation-modulated fashion. J Cell Biol 149:547-552

Ku NO, Gish R, Wright TL, Omary MB (2001) Keratin 8 mutations in patients with cryptogenic liver disease. N Engl J Med 344:1580 1587

Ku NO, Michie S, Resurreccion EZ, Broome RL, Omary MB (2002a) Keratin binding to 14-3-3 proteins modulates keratin filaments and hepatocyte mitotic progression. Proc Natl Acad Sci USA 99:4373-4378

Ku NO, Azhar S, Omary MB (2002b) Keratin 8 phosphorylation by p38 kinase regulates cellular keratin filament reorganization: modulation by a keratin 1-like disease causing mutation. J Biol Chem 277:10775-10782

Ku NO, Darling JM, Krams SM, Esquivel CO, Keeffe EB, Sibley RK, Lee YM, Wright TL, Omary MB (2003a) Keratin 8 and 18 mutations are risk factors for developing liver disease of multiple etiologies. Proc Natl Acad Sci USA 100:6063-6068

Ku NO, Soetikno RM, Omary MB (2003b) Keratin mutation in transgenic mice predisposes to Fas but not TNF-induced apoptosis and massive liver injury. Hepatology 37:1006-1014

Ku NO, Lim JK, Krams SM, Esquivel CO, Keeffe EB, Wright TL, Parry DAD, Omary MB (2005) Keratins as susceptibility genes for end-stage liver disease. Gastroenterology 129:885-893

Ku NO, Omary MB (2006) A disease- and phosphorylation-related nonmechnical function for keratin 8. J Cell Biol 174:115-125

Ku NO, Strnad P, Zhang BH, Tao GZ, Omary BM (2007) Keratins let liver live: mutations predispose to liver disease and crosslinking generates Mallory-Denk bodies. Hepatology 46:1639-1649

Kuusisto E, Salminen A, Alafuzoff I (2001) Ubiquitin-binding protein p62 is present in neuronal and glial inclusions in human tauopathies and synucleinopathies. NeuroReport 12:2085-2090

Lane EB, McLean WH (2004) Keratins and skin disorders. J Pathol 204:355-366
Lackner C, Gogg-Kamerer M, Zatloukal K, Stumptner C, Brunt EM, Denk H (2008) Ballooned hepatocytes in steatohepatitis: The value of keratin immunohistochemistry for diagnosis. J Hepatol $48: 821-828$

Lefkowitch JH (2005) Morphology of alcoholic liver disease. Clin Liver Dis 9:37-53

Lee WC, Yoshihara M, Littleton JT (2004) Cytoplasmic aggregates trap polyglutamine-containing proteins and block axonal transport in a Drosophila model of Huntington's disease. Proc Natl Acad Sci U S A 101:3224-3229

Leers MP, Kolgen W, Bjorklund V, Bergman T, Tribbick G, Persson B, Bjorklund P, Ramaekers FC, Bjorklund B, Nap M, Jornvall H, Schutte B (1999) Immunocytochemical detection and mapping of a cytokeratin 18 neo-epitope exposed during early apoptosis. J Pathol 187:567-572

Lewis DF, Ioannides C, Parke DV (1989) Molecular orbital studies of oxygen activation and mechanisms of cytochromes P-450-mediated oxidative metabolism of xenobiotics. Chem Biol Interact 70:263-280

Li J, Bardag-Gorce F, Dedes J, French BA, Amidi F, Oliva J, French SW (2008) S-adenosylmethionine prevents Mallory Denk body formation in drug-primed mice by inhibiting the epigenetic memory. Hepatology 47:613-624

Lindsten K, de Vrij FM, Verhoef LG, Fischer DF, van Leeuwen FW, Hol EM, Masucci MG, Dantuma NP (2002) Mutant ubiquitin found in neurodegenerative disorders is a ubiquitin fusion degradation substrate that blocks proteasomal degradation. J Cell Biol 157:417-427

Macario AJ, Conway de Macario E (2005) Sick chaperones, cellular stress, and disease. N Engl J Med 353:1489-1501

Magin TM (1998) Lessons from keratin transgenic and knockout mice. Subcell Biochem 31:141-172

Magin TM, Schroder R, Leitgeb S, Wanninger F, Zatloukal K, Grund C, Melton DW (1998) Lessons from keratin 18 knockout mice: formation of novel keratin filaments, secondary loss of keratin 7 and accumulation of liver-specific keratin 8-positive aggregates. J Cell Biol 140:1441-1451

Malhi H, Gores GJ, Lemasters JJ (2006) Apoptosis and necrosis in the liver: a tale of two deaths? Hepatology 43:S31-S44

Mallory F (1911) Cirrhosis of the liver. Five different types of lesions from which it may arise. Bul Johns Hopkins Hosp 22:69-75

Mantena SK, King AL, Andringa KK, Eccleston HB, Bailey SM (2008) Mitochondrial dysfunction and oxidative stress in the pathogenesis of alcohol- and obesity-induced fatty liver diseases. Free Radic Biol Med 44:1259-1272

Marceau N, Schutte B, Gilbert S, Loranger A, Henfling ME, Broers JL, Mathew J, Ramaekers FC (2007) Dual roles of intermediate filaments in apoptosis. Exp Cell Res 313:2265-2281

Marks GS, Allen DT, Johnston CT, Sutherland EP, Nakatsu K, Whitney RA (1985) Suicidal destruction of cytochrome P-450 and reduction of ferrochelatase activity by 3 , 5-diethoxycarbonyl-1, 4-dihydro-2, 4, 6-trimethylpyridine and its analogues in chick embryo liver cells. Mol Pharmacol 27:459-465

Matteoni CA, Younossi ZM, Gramlich T, Boparai N, Liu YC, McCullough AJ (1999) Nonalcoholic fatty liver disease: a spectrum of clinical and pathological severity. Gastroenterology 116:1413-1419

McPhaul LW, Wang J, Hol EM, Sonnemans MA, Riley N, Nguyen V, Yuan QX, Lue YH, Van Leeuwen FW, French SW (2002) Molecular misreading of the ubiquitin B gene and hepatic mallory body formation. Gastroenterology 122:1878-1885

Mehta K, Van Thiel DH, Shah N, Mobartan S (2002) Nonalcoholic fatty liver disease: pathogenesis and the role of antioxidants. Nutr Rev 60:289-293

Mendler MH, Kanel G, Govindarajan S (2005) Proposal for a histological scoring and garding system for non-alcoholic fatty liver disease. Liver Int 25:294-304 
Moll R, Franke WW, Schiller DL, Geiger B, Krepler R (1982) The catalog of human cytokeratins: patterns of expression in normal epithelia, tumors and cultured cells. Cell 31:11-24

Moscat J, Diaz-Meco MT, Wooten MW (2007) Signal integration and diversification through the p62 scaffold protein. Trends Biochem Sci 32:95-100

Müller T, Langner C, Fuchsbichler A, Heinz-Erian P, Ellemunter H, Schlenck B, Bavdekar AR, Pradhan AM, Pandit A, Müller-Hocker J, Melter M, Kobayashi K, Nagasaka H, Kikuta H, Müller W, Tanner MS, Sternlieb I, Zatloukal K, Denk H (2004) Immunohistochemical analysis of Mallory bodies in Wilsonian and non-Wilsonian hepatic copper toxicosis. Hepatology 39:963-969

Nakamichi I, Hatakeyama S, Nakayama KI (2002) Formation of Mallory body-like inclusions and cell death induced by deregulated expression of keratin 18. Mol Biol Cell 13:3441-3451

Nakamichi I, Toivola DM, Strnad P, Michie SA, Oshima RG, Baribault H, Omary MB (2005) Keratin 8 overexpression promotes mouse Mallory body formation. J Cell Biol 171:931-937

Nan L, Dedes J, French BA, Bardag-Gorce F, Li J, Wu Y, French SW (2006) Mallory body (cytokeratin aggresomes) formation is prevented in vitro by p38 inhibitor. Exp Mol Pathol 80:228-240

Nezis IP, Simonsen A, Sagona AP, Finley K, Gaumer S, Contamine D, Rusten TE, Stenmark H, Brech A (2008) Ref(2) P, the Drosophila melanogaster homologue of mammalian $\mathrm{p} 62$, is required for the formation of protein aggregates in adult brain. J Cell Biol 180:1065-1071

Omary MB, Ku NO, Liao J, Price D (1998) Keratin modifications and solubility properties in epithelial cells and in vitro. Subcell Biochem 31:105-140

Omary MB, Ku NO, Toivola DM (2002) Keratins: guardians of the liver. Hepatology 35:251-257

Omary MB, Coulombe PA, McLean WHI (2004) Mechanism of disease. Intermediate filament proteins and their associated diseases. N Engl J Med 351:2087-2100

Omary MB, Ku NO, Tao GZ, Toivola DM, Liao J (2006) "Heads and tails" of intermediate filament phosphorylation: multiple sites and functional insights. Trends Biochem Sci 31:383-394

Orrego H, Blake JE, Blendis LM, Medline A (1987) Prognosis of alcoholic cirrhosis in the presence and absence of alcoholic hepatitis. Gastroenterology 92:208-214

Oshima RG (2002) Apoptosis and keratin intermediate filaments. Cell Death Differ 9:486-492

Owens DW, Wilson NJ, Hill AJ, Rugg EL, Porter RM, Hutcheson AM, Quinlan RA, van Heel D, Parkes M, Jewell DP, Campbell SS, Ghosh S, Satsangi J, Lane EB (2004) Human keratin 8 mutations that disturb filament assembly observed in inflammatory bowel disease patients. J Cell Sci 117:1989-1999

Owens DW, Lane EB (2004) Keratin mutations and intestinal pathology. J Pathol 204:377-385

Pallari HM, Eriksson JE (2006) Intermediate filaments as signaling platforms. Sci STKE 19:pe53

Parola M, Robino G (2001) Oxidative stress-related molecules and liver fibrosis. J Hepatol 35:297-306

Pekny M, Pekna M (2004) Astrocyte intermediate filaments in CNS pathologies and regeneration. J Pathol 204:428-437

Pessayre D (2007) Role of mitochondria in non-alcoholic fatty liver disease. J Gastroenterol Hepatol 22:S20-S27

Ramesh Babu J, Lamar Seibenhener M, Peng J, Strom AL, Kemppainen R, Cox N, Zhu H, Wooten MC, Diaz-Meco MT, Moscat J, Wooten MW (2007) Genetic inactivation of p62 leads to accumulation of hyperphosphorylated tau and neurodegeneration. J Neurochem in press

Ray MB (1987) Distribution patterns of cytokeratin antigen determinants in alcoholic and nonalcoholic liver diseases. Hum Pathol 18:61-66
Riley NE, Li J, Worrall S, Rothnagel JA, Swagell C, van Leeuwen FW, French SW (2002) The Mallory body as an aggresome: in vitro studies. Exp Mol Pathol 72:17-23

Riley NE, Li J, McPhaul LW, Bardag-Gorce F, Lue YH, French SW (2003) Heat shock proteins are present in Mallory bodies (cytokeratin aggresomes) in human liver biopsy specimens. Exp Mol Pathol 74:168-172

Ross CA, Poirier MA (2004) Protein aggregation and neurodegenerative disease. Nat Med 10:S10-S17

Schalinske KL, Nieman KM (2005) Disruption of methyl group metabolism by ethanol. Nutr Rev 63:387-391

Schweizer J, Bowden PE, Coulombe PA, Langbein L, Lane EB, Magin TM, Maltais L, Omary MB, Parry DA, Rogers MA, Wright MW (2006) New consensus nomenclature for mammalian keratins. J Cell Biol 174:169-174

Seibenhener ML, Babu JR, Geetha T, Wong HC, Krishna NR, Wooten MW (2004) Sequestosome 1/p62 is a polyubiquitin chain binding protein involved in ubiquitin proteasome degradation. Mol Cell Biol 24:8055-8068

Shin J (1998) P62 and the sequestosome, a novel mechanism for protein metabolism. Arch Pharm Res 21:629-633

Smith RA, Porteous CM, Gane AM, Murphy MP (2003) Delivery of bioactive molecules to mitochondria in vivo. Proc Natl Acad Sci U S A 100:5407-54012

Stenoien DL, Cummings CJ, Adams HP, Mancini MG, Patel K, DeMartino GN, Marcelli M, Weigel NL, Mancini MA (1999) Polyglutamine-expanded androgen receptors form aggregates that sequester heat shock proteins, proteasome components and SRC1 , and are suppressed by the HDJ-2 chaperone. Hum Mol Genet 8:731-741

Stone MR, O’Neill A, Lovering RM, Strong J, Resneck WG, Reed PW, Toivola DM, Ursitti JA, Omary MB, Bloch RJ (2007) Absence of keratin 19 in mice causes skeletal myopathy with mitochondrial and sarcolemmal reorganization. J Cell Sci 120:39994008

Strnad P, Lienau TC, Tao GZ, Lazzeroni LC, Stickel F, Schuppan D, Omary MB (2006) Keratin variants associate with progression of fibrosis during chronic hepatitis $\mathrm{C}$ infection. Hepatology 43:1354-1363

Strnad P, Harada M, Siegel M, Terkeltaub RA, Graham RM, Khosla C, Omary MB (2007) Transglutminase-2 regulates Mallory body inclusion formation and injury associated liver hypertrophy. Gastroenterology 132:1515-1526

Strnad P, Tao GZ, Zhou Q, Harada M, Toivola DM, Brunt EM, Omary MB (2008) Keratin mutation predisposes to mouse liver fibrosis and unmasks differential effects of the carbon tetrachloride and thioacetamide models. Gastroenterology 134:1169-1179

Strnad P, Tao GZ, So P, Lau K, Schilling J, Wei Y, Liao J, Omary MB "Toxic memory" via chaperone modification is a potential mechanism for rapid Mallory-Denk body induction. Hepatology submitted

Stumptner C, Heid H, Fuchsbichler A, Hauser H, Mischinger HJ, Zatloukal K, Denk H (1999) Analysis of intracytoplasmic hyaline bodies in a hepatocellular carcinoma. Demonstration of p62 as major constituent. Am J Pathol 154:1701-1710

Stumptner C, Omary MB, Fickert P, Denk H, Zatloukal K (2000) Hepatocyte cytokeratins are hyperphosphorylated at multiple sites in human alcoholic hepatitis and in a Mallory body mouse model. Am J Pathol 156:77-90

Stumptner C, Fuchsbichler A, Heid H, Zatloukal K, Denk H (2002) Mallory body-a disease associated type of sequestosome. Hepatology 35:1053-1062

Stumptner C, Fuchsbichler A, Zatloukal K, Denk H (2007) In vitro production of Mallory bodies and intracellular hyaline bodies: the central role of sequestosome 1/p62. Hepatology 46:851-860 
Suhr ST, Senut MC, Whitelegge JP, Faull KF, Cuizon DB, Gage FH (2001) Identities of sequestered proteins in aggregates from cells with induced polyglutamine expression. J Cell Biol 153:283-294

Tao GZ, Toivola DM, Zhong B, Michie SA, Resurreccion EZ, Tamai Y, Taketo MM, Omary MB (2003) Keratin-8 null mice have different gallbladder and liver susceptibility to lithogenic diet-induced injury. J Cell Sci 116:4629-4638

Tao GZ, Zhou Q, Strnad P, Salemi MR, Lee YM, Omary MB (2005) Human Ran cysteine-112 oxidation by pervanadate regulates its binding to keratins. J Biol Chem 280:12162-12167

Tao GZ, Strnad P, Zhou Q, Kamal A, Zhang L, Madani ND, Kugathasan S, Brant SR, Cho JH, Omary MB, Duerr RH (2007) Analysis of keratin polypeptides 8 and 19 variants in inflammatory bowel disease. Clin Gastroenterol Hepatol 5:857-864

Tao GZ, Li D, Zhou Q, Toivola D, Strnad P, Sandesara N, Cheung R, Hong A, Omary M (2008) Monitoring of epithelial cell caspase activation via detection of durable keratin fragment formation. $\mathrm{J}$ Pathol in press

Tarantino G, Conca P, Coppola A, Vecchione R, Di Minno G (2007) Serum concentrations of the tissue polypeptide specific antigen in patients suffering from non-alcoholic steatohepatitis. Eur J Clin Invest 37:48-53

Tephly TR, Gibbs AH, Ingall G, De Matteis F (1980) Studies on the mechanism of experimental porphyria and ferrochelatase inhibition produced by 3, 5-diethoxycarbonyl-1, 4-dihydrocollidine. Int J Biochem 12:993-998

Tephly TR, Coffman BL, Ingall G, Ziet-Har MS, Goff HM, Tabba HD, Smith KM (1981) Identification of N-methylprotoporphyrin IX in livers of untreated mice and mice treated with 3, 5-diethoxycarbonyl- 1, 4-dihydrocollidine: source of the methyl group. Arch Biochem Biophys 212:120-126

Toivola DM, Ku NO, Resurreccion EZ, Nelson DR, Wright TL, Omary MB (2004) Keratin 8 and 18 hyperphosphorylation is a marker of progression of human liver disease. Hepatology 40:459-466

Toivola DM, Tao GZ, Habtezion A, Liao J, Omary MB (2005) Cellular integrity plus: organelle-related and protein-targeting functions of intermediate filaments. Trends Cell Biol 15:608-617

Vadlamudi RK, Joung I, Strominger JL, Shin J (1996) P62, a phosphotyrosine-independent ligand of the $\mathrm{SH} 2$ domain of p56lck, belongs to a new class of ubiquitin-binding proteins. J Biol Chem 271:20235-20237

Van Eyken P, Sciot R, Callea F, Van der Steen K, Moerman P, Desmet VJ (1988) The development of the intrahepatic bile ducts in man: a keratin-immunohistochemical study. Hepatology 8:1586-1595

Vassy J, Irinopoulou T, Beil M, Rigaut JP (1997) Spatial distribution of cytoskeleton intermediate filaments during fetal rat hepatocyte differentiation. Microsc Res Tech 39:436-443

Venkatraman P, Wetzel R, Tanaka M, Nukina N, Goldberg AL (2004) Eukaryotic proteasomes cannot digest polyglutamine sequences and release them during degradation of polyglutamine-containing proteins. Mol Cell 14:95-104
Villeneuve JP, Pichette V (2004) Cytochrome P450 and liver diseases. Curr Drug Metab 5:273-282

Volkmann X, Cornberg M, Wedemeyer H, Lehner F, Manns MP, Schulze-Osthoff K, Bantel H (2006) Caspase activation is required for antiviral treatment response in chronic hepatitis $\mathrm{C}$ virus infection. Hepatology 43:1311-1316

Wang Z, Figueiredo-Pereira ME (2005) Inhibition of sequestosome 1/p62 upregulation prevents aggregation of ubiquitinated proteins induced by prostaglandin $\mathrm{J} 2$ without reducing its neurotoxicity. Mol Cell Neurosci 29:222-231

Wick MR (2000) Immunohistology of neuroendocrine and neuroectodermal tumors. Semin Diagn Pathol 17:194-203

Wieckowska A, Zein NN, Yerian LM, Lopez AR, McCullough AJ, Feldstein AE (2006) In vivo assessment of liver cell apoptosis as a novel biomarker of disease severity in nonalcoholic fatty liver disease. Hepatology 44:27-33

Williams A, Jahreiss L, Sarkar S, Saiki S, Menzies FM, Ravikumar B, Rubinsztein DC (2006) Aggregate-prone proteins are cleared from the cytosol by autophagy: therapeutic implications. Curr Top Dev Biol 76:89-101

Wöll S, Windoffer R, Leube RE (2007) p38 MAPK-dependent shaping of the keratin cytoskeleton in cultured cells. J Cell Biol 177:795807

Wooten MW, Geetha T, Babu JR, Seibenhener ML, Peng J, Cox N, Diaz-Meco MT, Moscat J (2008) Essential role of SQSTM1/p62 in regulating accumulation of K63-ubiquitinated proteins. J Biol Chem 283:6783-6789

Yokoo H, Minick OT, Batti F, Kent G (1972) Morphologic variants of alcoholic hyaline. Am J Pathol 69:25-40

Yokoo H, Harwood TR, Racker D, Arak S (1982) Experimental production of Mallory bodies in mice by diet containing 3, 5-diethoxycarbonyl-1, 4-dihydrocollidine. Gastroenterology 83:109-113

Zatloukal K, Fesus L, Denk H, Tarcsa E, Spurej G, Böck G (1992) High amount of $\varepsilon$-( $\gamma$-glutamyl) lysine cross links in Mallory bodies. Lab Invest 66:774-777

Zatloukal K, Stumptner C, Lehner M, Denk H, Baribault H, Eshkind LG, Franke WW (2000) Cytokeratin 8 protects from hepatotoxicity, and its ratio to cytokeratin 18 determines the ability of hepatocytes to form Mallory bodies. Am J Pathol 156:1263-1274

Zatloukal K, Stumptner C, Fuchsbichler A, Heid H, Schnoelzer M, Kenner L, Kleinert R, Prinz M, Aguzzi A, Denk H (2002) P62 is a common component of cytoplasmic inclusions in protein aggregation diseases. Am J Pathol 160:255-263

Zatloukal K, Stumptner C, Fuchsbichler A, Fickert P, Lackner C, Trauner M, Denk H (2004) The keratin cytoskeleton in liver diseases. J Pathol 204:367-376

Zatloukal K, French SW, Stumptner C, Strnad P, Harada M, Toivola DM, Cadrin M, Omary MB (2007) From Mallory to MalloryDenk bodies: what, how and why? Exp Cell Res 313:2033-2049

Zhou Q, Ji X, Chen L, Greenberg HB, Lu SC, Omary MB (2005) Keratin mutation primes mouse liver to oxidative injury. Hepatology 41:517-525 